DOI 10.18551/rjoas.2020-08.14

\title{
ECONOMIC MARKET DECISIONS AMONG MARGINAL MAIZE FARMERS IN ABUJA, NIGERIA: APPLICATIONS OF DOUBLE HURDLE MODEL AND FACTOR ANALYSIS
}

\author{
Alabi Olugbenga Omotayo* \\ Department of Agricultural Economics, University of Abuja, Gwagwalada-Abuja, Nigeria \\ Oladele Ayoola Olugbenga \\ Department of Agricultural Extension and Management, Federal College of Forestry \\ Mechanization, Forestry Research Institute of Nigeria, Kaduna, Nigeria
}

Oladele Nath Olarotimi

Trial Afforestation Research Station, Forestry Research Institute of Nigeria, Kaduna, Nigeria

\section{*E-mail: omotayoalabi@yahoo.com}

\begin{abstract}
This study examined economic market decisions among marginal maize farmers in Abuja, Nigeria: applications of double hurdle model and factor analysis. Specifically, the objectives were designed and stated to achieve the following; describe the socio-economic characteristics of marginal maize farmers, analyze the costs and returns of marginal maize production, determine the marginal productivities of maize farmers, estimate the factors influencing output of marginal maize production, evaluate factors influencing market decisions among marginal maize farmers, and identify the constraints facing marginal maize farmers. Multi-stage sampling technique was adopted and used. Primary data were collected from marginal maize producers through the use of well-structured and well-designed questionnaire. Data obtained were coded and analyzed using descriptive statistics, gross margin analysis, financial analysis, double-log functional model, marginal productivity, double-hurdle model, and principal component analysis. The results show that $60 \%$ of marginal maize farmers were less than 50 years of age. About $80 \%$ of farmers had less than 20 years experiences in maize farming. The mean farm size was 1.19 hectares of land. The gross margin and net farm income were 577,300 Naira and 525,300 Naira respectively. The gross margin ratio, operating ratio, and rate of return on investment were $0.82,0.21$, and 3.01 respectively. The gross margin ratio of 0.82 implies that for every one Naira invested in maize production by marginal farmers 82 kobo covered profits, taxes, interest, expenses, and depreciation. Marginal productivity analysis revealed that resources such as fertilizers, seeds, and land were under-utilized. Factors influencing output of maize production by marginal farmers were: farm size $(<0.01)$, family labour $(P<0.05)$, hired labour $(P<0.05)$, fertilizers $(P<0.01)$, seed input $(P<0.05)$, and volume of pesticide used $(P<0.10)$. The double-hurdle model revealed that age $(P<0.01)$, prices output of maize $(P<0.05)$, education status $(P<0.10)$, distant to nearby market $(P<0.05)$, access to extension agents $(P<0.01)$ and access to credit facilities $(P<0.05)$ were statistically and significant variables influencing marginal maize farmers decisions to market participation. The retained constraints facing marginal maize farmers explained $96.46 \%$ of variables included in the model. Factors analysis shows that retained constraints facing marginal maize farmers were; bad road infrastructures, lack of access to credit facilities, inadequate extension officers, poor storage facilities, lack of production inputs, and lack of new, improved technologies.
\end{abstract}

\section{KEY WORDS}

Marginal maize farmers, market decisions, double hurdle model, factor analysis, Nigeria.

Maize (Zea mays) is very good source of minerals, carbohydrate, vitamin B and protein for people of sub-Saharan Africa. After sorghum, and millet, maize came third as an important cereal and Nigerian staple food crop. Maize is used in the following areas: corn 
syrup, starch, for feeding livestock, protein and oil, food sweeteners, beverages, fuel, sugars, corn flakes, biscuits, dextrose, baking and brewing, use in industries. The major industries using maize can be stated as: livestock industries, pharmaceutical industries, food and confectionary industries, beverages industries. About $90 \%$ of Nigerian farmers are subsistence in nature otherwise called smallholder, marginal, peasant or smallscale. The characteristics of marginal farmers are: they have low capital base, use crude implements with low level of technology, they are poor, and the yield obtained per hectare of land is low (Ojo, 2000). They produce to feed the families and also offer some produce for sale. Marginal farmers are further faced with price instability or fluctuations, pest and diseases infestations, lack of storage facilities, and resources they have are not efficiently used, this makes the production of maize to be low. The demands for maize outweigh the supply of maize. Maize can also be used for particleboard, papers, adhesives, detergent, plastics, for weaning foods or for production of traditional African beer. Maize can be used in composite flour breads and cakes. Therefore, understanding the marginal farmers in maize production will be very helpful for policy makers in formulating policies that will help the agricultural sector. Market opportunities and value chain that are integrated has opportunities to transform agriculture in Africa. Africa has the great potentials of expanding market opportunities and can enhance long term private investors to undertake agro-processing and agribusiness. Africa's economy presently may not be able to compete globally, this is because the agriculture are mainly marginal or smallscale in nature and the markets are fragmented and small (Mulat et al, 2006). Changes in food and agricultural markets are needed in sub- Saharan Africa, such as quality products demanded, increase in value of crops, food safety for African export countries, branding, and packaging (Reardon et al, 2012).Marginal farmers are faced with two critical decisions, firstly, they are faced with the task of meeting food security needs, and secondly, they are faced with the need to produce enough products surpluses to sell in the market. Marginal farmers are faced with a lot of constraints which make it difficult or reduce their participations in the market, marginal farmers lack access to information, required assets, and sufficient means to overcome needed cost to enter markets (Uchezuba, Moshabele, and Digopo, 2009).Marginal farmers lack the knowledge regarding marketing strategy, they either sell most of their crops at lower prices at the farm gates or at local markets (Gyau, Mbugua, and Odoul, 2006).Marginal farmers have limited access to acquisition of inputs for production, their farm sizes are usually less than 2 or 3 hectares of land, and do not have guaranteed markets for their farm produce (Gyau et al, 2006). Countries with high proportion of marginal farmers or smallscale farmers or smallholder farmers are often recognized as low-income countries or developing nations (Lowder, Skoet, and Raney, 2016). Accumulation of private assets, public services and infrastructures are what marginal, smallholder farmers need to move from subsistence agricultural production and produce surpluses for markets (Barret, 2008). Marginal farmers lost a lot of produce after production to spoilage of produce and inability of them to access markets. Appropriate marketing decisions may help marginal farmers increase their profitability, change their production, be able to invest in productive assets, procure new agricultural technologies, adopt new innovations, and as well improve welfare of the household (Jensen, 2010).

Objectives of the Study. The study was designed in broad terms to evaluate economic market decisions among marginal maize farmers in Abuja, Nigeria: applications of double hurdle model and factors analysis. Specifically, the study was designed to achieve the following objectives: determine the socio-economic characteristics of marginal maize farmers; analyze the costs and returns of marginal maize production; determine the marginal productivity of maize farmers; evaluate factors influencing or affecting output of marginal maize production; evaluate factors influencing or affecting market decisions among marginal maize farmers, and determine constraints or problems facing marginal maize farmers. 


\section{METHODS OF RESEARCH}

The Study Area. The study was conducted in Gwagwalada, Abuja, Nigeria. Gwagwalada is an area council located at Latitudes $8055^{\prime}$ 59" North of the Equator and Longitudes 70 5' 59" East of the meridian. The study area was characterized by high humidity, which has a heat trap effect. There are notably two main seasons; the wet and dry. Annual rainfall, ranges from $1100 \mathrm{~mm}$ to $1700 \mathrm{~mm}$. The climatic conditions of the study area permit agricultural activities such as cultivation of crops, grazing of animals and fishery production. Gwagwalada Area Council has a total land mass of about 1,043 Square Kilometer and with a population of 157,770 people (NPC, 2006). Average annual rainfall ranges from 800 to $1,500 \mathrm{~mm}$ and temperature ranges between $21^{\circ} \mathrm{C}-35^{\circ} \mathrm{C}$.

Sampling Techniques and Sample Size. Purposive sampling technique was adopted and employed in choosing Abuja, Nigeria. This is because of predominant smallholder or marginal maize farmers in the area. Multi-stage was adopted and employed in choosing the marginal farmers. First stage involves the selection of Gwagwalada out of six (6) area councils using simple random sampling technique employing ballot-box raffle draw method. Second stage involves the selection five (5) wards out of ten (10) wards using simple random selection technique employing ballot-box raffle draw method. Third stage involves the selection of two (2) villages per ward using simple random sampling technique employing ballot-box raffle draw method. Fourth and final stage involves the selection of five (5) marginal maize farmers they are the target respondents, the marginal farmers were selected using simple random sampling technique employing ballot-box raffle draw method. The total sample size was 100 marginal maize farmers in the area.

Method of Data Collection. This study employed primary data. Primary data involves the use of well-designed and well-structured questionnaire. The questionnaire was designed to capture all variables necessary to achieve the broad objective and specific objectives stated to be achieved. The questionnaire captured variables like the socio-economic characteristics of marginal maize farmers such as age, household size, experiences in maize production, marital status, and educational status. The questionnaire was also designed to capture the cost involved and revenue obtained in maize production, output of marginal maize producers, and constraints or problem facing marginal maize producers. The questionnaire was subjected to reliability and validity tests. The questionnaire was designed taking notice of observations arising from reliability and validity tests conducted. The questionnaire was administered to marginal maize farmers with the help of well-trained enumerators.

Method of Data Analysis. The following statistical and econometric tools were used to achieve the stated broad and specific objectives: Descriptive Statistics; Gross Margin Analysis; Financial Analysis; Cobb-Douglas Model; Marginal Productivity; Five Point Likert Scale; Double Hurdle Model; Stage One: Probit Model; Stage Two: Tobit Model; Principal Component Analysis; t-Test Analysis, and Z-Test Analysis.

Descriptive Statistics. This involves or encompasses the use of mean, frequency distributions, percentages. Descriptive statistics was used to have a summary statistics of data obtained from the field. This was used to achieve specific objectives one (i), and six (vi) which identifies the socio-economic characteristics of marginal maize farmers and constraints or problems facing smallscale or marginal maize farmers.

Gross Margin Analysis. Gross Margin Analysis is defined as the difference between the observed gross farm income (GFI) and total variable cost (TVC) (Olukosi and Erhabor, 2005). It was used to determine the potentials profitability of marginal maize farmers. The tools were used to achieve specific objective two (ii).

Gross margin model (GM) is expressed as follows:

$$
G M=T R-T V C
$$


Where: $\mathrm{GM}=$ Gross Margin ( $\mathrm{A})$, TR = Total Value of Output or Total Revenue from the

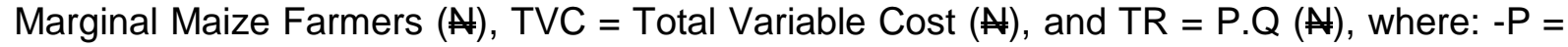
Price of Maize Produced in Naira per Kilogram, $Q=$ Output of Maize Produced in Kilogram.

Net Farm Income (NFI) is stated thus:

$$
N F I=\sum_{i=1}^{n} P_{1} Y_{i}-\sum_{j=i}^{m} P_{j} X_{j}-\sum_{k=1}^{k} G K \ldots \ldots
$$

Where: NFI = Net Farm Income (Naira Per annum), $P_{i}=$ Unit Price of Product (Naira/Unit), $P_{j}=$ Price per Unit Variable Input (Naira/Unit), GK = Cost of all Fixed Inputs (where $k=1,2,3$, ....k fixed input), $\Sigma=$ Summation or Addition signs.

This was used to achieve part of specific objective two (ii).

Financial Analysis. Gross Margin Ratio (GMR) following Ben-Chendo (2015) was used to determine the profitability of marginal maize production. This was used to achieve part of specific objective two (ii)

$$
\text { Gross Margin Ratio }=\frac{\text { Gross Margin }}{\text { Total Revenue }}
$$

In order to evaluate the strength and financial positions of marginal maize enterprises, operating ratio and rate of return per naira invested were considered. An operating ratio $(\mathrm{OR})$ according to Olukosi and Erhabor (2005) is stated thus:

$$
O R=\frac{T V C}{G I}
$$

Where: OR = Operating Ratio (Units), TVC= Total Variable Cost (Naira), GI = Gross Income (Naira).

An Operating Ratio (OR) that is less than one (1) implies that the total revenue obtained from marginal maize production was able to pay for the cost of variable inputs used in the enterprise (Olukosi and Erhabor, 2005). The rate of return per naira invested (RORI) in maize production is stated thus:

$$
R O R I=\frac{N I}{T C}
$$

Where: RORI = Rate of Return per Naira Invested (Units), $\mathrm{NI}=$ Net Income from Marginal Maize Production (Naira), TC $=$ Total Cost (Naira).

The financial analysis was used to achieve part of specific objective two (ii)

Marginal Productivity Index. Marginal Productivity is defined as:

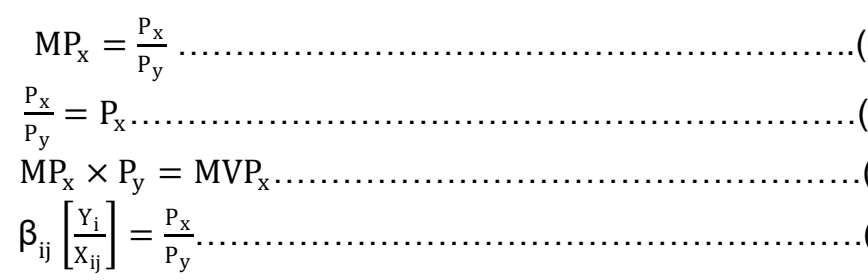

Where: $P_{x}=$ Unit Cost of Each Resources Employed (Naira), $P_{y}=$ Price of Output (Naira), $\mathrm{MVP}_{\mathrm{x}}=$ Marginal Value Product of $x$, $\mathrm{MP}_{\mathrm{x}}=$ Marginal Productivity of $x$, $\beta_{\mathrm{ij}}=$ Elasticities of Inputs, $\beta_{\mathrm{ij}}\left[\frac{Y_{\mathrm{i}}}{\mathrm{X}_{\mathrm{ij}}}\right]=$ Marginal Product $\left(\mathrm{MP}_{\mathrm{x}}\right)$ of the Input.

$\mathrm{MVP}_{\mathrm{x}}>\mathrm{P}_{\mathrm{x}}=$ Under Utilization of Input

$\mathrm{MVP}_{\mathrm{x}}<\mathrm{P}_{\mathrm{x}}=$ Over Utilization of Input.

$\mathrm{MVP}_{\mathrm{x}}=\mathrm{P}_{\mathrm{x}}=$ Optimum Input Utilization 
(iii).

The Marginal Productivity analysis was used to achieve part of specific objective three Cobb-Douglas Production Model. The Cobb-Douglas Production Model is stated thus;

$\log Y=\log \beta_{0}+\beta_{1} \log X_{1}+\beta_{2} \log X_{2}+\beta_{3} \log X_{3}+\beta_{4} \log X_{4}+\beta_{5} \log X_{5}+\beta_{6} \log X_{6}+\mu_{i}$

Where:

$\mathrm{Y}=$ Output of Marginal Maize Production (Kg);

$\mathrm{X}_{1}=$ Farm Size $(\mathrm{Ha})$;

$\mathrm{X}_{2}=$ Family Labour (Mandays);

$\mathrm{X}_{3}=$ Hired Labour (Mandays);

$\mathrm{X}_{4}=$ Fertilizers $(\mathrm{Kg})$;

$\mathrm{X}_{5}=$ Seed Input $(\mathrm{Kg})$

$\mathrm{X}_{6}=$ Pesticides (Litres);

$\beta_{0}=$ Constant Term;

$\beta_{1}-\beta_{6}=$ Regression Coefficients;

$\mu_{\mathrm{i}}=$ Error Term.

The Cobb-Douglas Production Model was used to achieve part of objective four (iv).

Double-Hurdle Model. The first step is Probit model is stated thus:

$$
Y=\beta_{0}+\beta_{1} X_{1}+\beta_{2} X_{2}+\beta_{3} X_{3}+\beta_{4} X_{4}+\beta_{5} X_{5}+\beta_{6} X_{6}+\mu_{i}
$$

Where:

$\mathrm{Y}=$ Dichotomous Dependent Variable (1, Participate in Market; 0, Otherwise);

$\mathrm{X}_{1}=$ Age (Years);

$\mathrm{X}_{2}=$ Prices Ouput of Maize $(\mathrm{Kg})$;

$\mathrm{X}_{3}=$ Education Status (0, Non - Formal; 1, Primary; 2, Secondary; 3, Tertiary)

$\mathrm{X}_{4}=$ Distant to Nearby Market (1, Far Distant; 0, Otherwise);

$\mathrm{X}_{5}=$ Access to Extension Agents (1, Access Extension Officers; 0, Otherwise);

$\mathrm{X}_{6}=$ Access to Credit Facilities ( 1 , Access ; 0, Otherwise);

$\beta_{0}=$ Constant Term;

$\beta_{1}-\beta_{6}=$ Regression Coefficients;

$\mu_{\mathrm{i}}=$ Error Term.

The second step is Tobit model, truncated regression model is stated thus:

$$
Y=\beta_{0}+\beta_{1} X_{1}+\beta_{2} X_{2}+\beta_{3} X_{3}+\beta_{4} X_{4}+\beta_{5} X_{5}+\beta_{6} X_{6}+\mu_{i}
$$

Where:

$\mathrm{Y}=$ Output of Marginal Maize Production (Kg);

$\mathrm{X}_{1}=$ Age (Years);

$\mathrm{X}_{2}=$ Marital Status (1, Married; 0, Otherwise);

$\mathrm{X}_{3}=$ Education Status (0, Non - Formal; 1, Primary; 2, Secondary; 3, Tertiary);

$\mathrm{X}_{4}=$ Distant to Nearby Market (1, Far Distant; 0, Otherwise);

$\mathrm{X}_{5}=$ Access to Extension Agents (1, Access Extension Officers; 0, Otherwise);

$\mathrm{X}_{6}=$ Access to Credit Facilities ( 1 , Access ; 0, Otherwise);

$\beta_{0}=$ Constant Term;

$\beta_{1}-\beta_{6}=$ Regression Coefficients.

The Double - Hurdle Model was used to achieve part of specific objective five (v).

Five Point Likert- Scale. To ascertain the perceptions of marginal maize farmers, problems and constraints faced by marginal maize farmers, Five-Point Likert- scale was used. To ascertain marginal maize farmers perceptions, the response options and values assigned were as follows: strongly agree $=5$; agree $=4$; undecided $=3$, disagree $=2$, and strongly disagree $=1$. These values were added and divided by 5 to obtain 3.0 , which was 
observed and regarded as the mean. Perceptions, or problems with mean scores (MS) greater than or equal to 3.0 was regarded as "Significant" while perceptions, or problems with mean responses lower than 3.0 was regarded as "Non-Significant". The mean scores for this study were calculated using the formula below:

$$
M S=\frac{\sum[R P \times O]}{\sum F} .
$$

Where: $M S=$ Mean Score (Units), RP = Rating Point (Units), $\mathrm{O}=$ Observations (Units), $\Sigma F=$ Total Number of Sampled Respondents (Units).

This was used to achieve part of specific objective six (vi).

Principal Component Analysis (PCA). The perceived constraints or problems faced by marginal maize farmers were analyzed using principal component analysis (PCA). The Model of Principal Component (PCA) is stated thus:

$$
\begin{aligned}
& x=x_{1}, x_{2}, x_{3}, \ldots, x_{p} \ldots \ldots \ldots \ldots \ldots \\
& \propto_{k}=\propto_{1 k 1}, \propto_{2} K, \propto_{3} k, \ldots, \propto p k \\
& \propto_{K}^{T} x=\sum_{j=1}^{p} \propto_{K j X j} \ldots \ldots \ldots \ldots \ldots \ldots \\
& \text { Var }=\left[\propto_{K}^{T} X\right] \text { is Maximum } \ldots .
\end{aligned}
$$

Subject to:

$$
\begin{aligned}
& \propto_{K}^{T} \propto_{K}=1 \ldots \ldots \ldots \ldots \ldots \ldots \\
& \operatorname{Cov}=\left[\propto_{1}^{T} \propto-\propto_{2}^{T} \propto\right]=0 .
\end{aligned}
$$

The Variance of each of the Principal Component:

$$
\begin{aligned}
& \operatorname{Var}\left[\propto_{k} X\right]=\lambda_{k} \ldots \ldots \ldots \ldots \ldots \ldots \ldots \\
& S=\frac{1}{n-1}(X-\bar{X})(X-\bar{X})^{T} \ldots \ldots \ldots \\
& S_{i}=\frac{1}{n-1} \sum_{i=1}^{n}\left(X_{i}-\bar{X}_{i}\right)\left(X_{I}-\bar{X}_{i}\right) \ldots
\end{aligned}
$$

Where: $\mathrm{X}=$ vector of 'P' Random Variables, $\alpha_{k}=$ Vector of 'P' Constraints, $\lambda_{k}=$ Eigen Value, $\mathrm{T}=$ Transpose, $\mathrm{S}=$ Sample Covariance Matrix.

This was used to achieve specific objective six (vi).

\section{RESULTS AND DISCUSSION}

Socio-Economic Characteristics of Marginal Maize Farmers. Table 1 shows the socioeconomic characteristics of marginal maize farmers. About $60 \%$ of marginal maize farmers were less than 50 years of age. Young and energetic farmers are able to withstand stress and adopt innovations. This result agrees or is in line with findings of Alabi and Ibraheem (2018), Udoh and Nyienekuma (2008). Education is an important factor that can influence marginal farmers to adopt new innovations and research findings. Most (97\%) of the marginal maize farmers had formal education. When a farmer is educated, there is high probability that he will take advantages of innovations and new technologies easily. This result agrees or is in line with Oluwatayo et al (2008). Experience of marginal maize farmers can be linked with age of the farmers. When the farmer gets older, he must have acquired more experiences in maize farming. About $80 \%$ of marginal maize farmers had less than 20 years' experience in maize farming. The mean household sizes were 6 people. The average 
farm size in hectares was 1.19 hectares. This means that the maize farmers were smallscale, peasant, marginal or smallholder.

Table 1 - Socio-Economic Characteristics of Marginal Maize Farmers

\begin{tabular}{|c|c|c|c|}
\hline Socio-Economic Characteristics & Frequency & Percentage & Mean \\
\hline Age (Years) & & & \\
\hline $31-40$ & 25 & 25.00 & \\
\hline $41-50$ & 35 & 35.00 & 47.00 \\
\hline $51-60$ & 40 & 40.00 & \\
\hline Marital Status & & & \\
\hline Single & 24 & 24.00 & \\
\hline Married & 49 & 49.00 & \\
\hline Widowed & 25 & 25.00 & \\
\hline Divorced & 02 & 02.00 & \\
\hline $\begin{array}{l}\text { Educational Status } \\
\text { (Years) }\end{array}$ & & & \\
\hline Primary & 41 & 41.00 & \\
\hline Secondary & 35 & 35.00 & \\
\hline Tertiary & 21 & 21.00 & \\
\hline Non-Formal & 03 & 03.00 & \\
\hline Experience in Maize & & & \\
\hline Farming (Years) & & & \\
\hline $1-10$ & 51 & 51.00 & \\
\hline $11-20$ & 29 & 29.00 & 12.40 \\
\hline $21-30$ & 20 & 20.00 & \\
\hline Household Size (Units) & & & \\
\hline $1-5$ & 65 & 65.00 & 5.75 \\
\hline $6-10$ & 15 & 15.00 & \\
\hline $11-15$ & 20 & 20.00 & \\
\hline Farm Size (Hectares) & & & \\
\hline $0.1-0.5$ & 17 & 17.00 & \\
\hline $0.6-0.9$ & 22 & 22.00 & 1.19 \\
\hline $1.0-1.5$ & 35 & 35.00 & \\
\hline $1.6-2.0$ & 13 & 13.00 & \\
\hline $2.1-2.5$ & 12 & 12.00 & \\
\hline $2.6-3.0$ & 01 & 01.00 & \\
\hline Total & 100 & 100.00 & \\
\hline
\end{tabular}

Source: Field Survey (2019), Computed from STATA Version 14.

This is based on the classifications of farm sizes of farmers according to Alabi and Ibraheem (2008) as: 0.1 - 5.0 hectares (smallscale, marginal, smallholder), 5.1 - 10 hectares (medium-scale), and 10 hectares and above (large-scale).

Costs and Returns of Marginal Maize Production. Table 2 shows the gross margin analysis of marginal maize farmers. The total variable cost was 122,700 Naira and this accounted for $70.24 \%$ of the total cost. The total fixed cost was 52,000 Naira and this accounted for $29.76 \%$ of the total cost.

Fertilizer input estimated value was 60,000 Naira and this accounted for $34.35 \%$ of the total variable cost. Depreciation of farm assets, tools and equipment's gave an estimated value of 24,500 Naira and this accounted for $14.02 \%$ of the total fixed cost. The calculated gross margin gave an estimated value of 577,300 Naira. The gross margin, operating ratio, and rate of return on marginal maize enterprises were $0.82,0.21$ and 3.10 respectively. The gross margin ratio of 0.82 implies that for every one Naira invested in maize production by marginal farmers, 82 kobo covered profits, interest, taxes, expenses, and depreciation. Furthermore, 18 kobo covered cost of operations of maize production. The net farm income was 525,300 Naira, this implies that marginal maize production was profitable. This result agrees or is in line with Alabi and Ibraheem (2018), Alabi, Amadi and ljir (2014).

Marginal Productivity of Maize Farmers. Table 3 shows the marginal productivity of maize farmers. The resources under study were fertilizer, seeds, labour, and land. The resources used were examined based on whether they were underutilized, over-utilized or optimum utilized. Fertilizer input, seed input, and land input were under-utilized. This implies 
that increasing the use of fertilizer, seeds and acquiring more hectares of land will increase the productivity of marginal maize farmers or increase the gross profit and minimizing the cost of production. Furthermore, resource efficiency of marginal maize farmers will be improved.

Table 2 - Costs and Returns of Marginal Maize Production

\begin{tabular}{|l|l|l|}
\hline Variable & Value (N) & Percentage \\
\hline (a) Variable Cost & & \\
Cost of Preparing Land & 17,500 & 10.02 \\
Labour Input & 31,700 & 18.15 \\
Seed Input & 3,500 & 02.00 \\
Fertilizer Input & 60,000 & 34.35 \\
Pesticides & 10,000 & 5.72 \\
Total Variable Cost $\quad 122,700$ & 70.24 \\
$\quad$ (b) Fixed Cost & & 14.02 \\
Depreciation of Farm Assets & 24,500 & 09.73 \\
Cost Incurred on Land & 17,000 & \\
Expenses Spent on & 5,000 & 02.86 \\
Administrative Procedures & 3,000 & 01.72 \\
Taxes & 2,500 & 01.43 \\
Interest & 52,000 & 29.76 \\
Total Fixed Cost & 174,700 & 100.00 \\
Total Cost of Production & 700,000 & \\
Total Returns & 577,300 & \\
Gross Margin & 525,300 & \\
Net Farm Income & 0.82 & \\
Gross Margin Ratio & 0.21 & \\
Operating Ratio & 3.01 & \\
Rate of Return on Investment & & \\
\hline
\end{tabular}

Source: Field Survey (2019), Computed using STATA Version 14.

Table 3 - Marginal Productivity of Maize Farmers

\begin{tabular}{|l|l|l|l|l|}
\hline Variable Input & \multicolumn{1}{|c|}{$\mathrm{MP}_{\mathrm{X}}$} & \multicolumn{1}{|c|}{$\mathrm{MVP}_{\mathrm{X}}$} & \multicolumn{1}{c|}{$\mathrm{P}_{\mathrm{X}}$} & Decision \\
\hline Fertilizer & 16.89 & 295,575 & 7,500 & Underutilization \\
Seeds & 13.66 & 239,050 & 4,500 & Underutilization \\
Labour & 00.25 & 4,375 & 5,500 & Overutilization \\
Land & 14.16 & 247,800 & 17,500 & Underutilization \\
\hline
\end{tabular}

Source: Field Survey (2019), Computed using STATA Version 14.

An increase use of labour input in marginal maize production will lead to decrease in gross profit. Therefore, for resource efficiency and high productivity, the size of labour utilized in marginal maize production should be reduced. This result agrees or is in line with findings of Alabi and Ibraheem (2018).

Factors Influencing or Affecting Output of Marginal Maize Production. Factors influencing or affecting output of marginal maize production were evaluated using CobbDouglas model. The explanatory or predictor or exogenous variable examined in the model were; farm size, family labour, hired labour, fertilizer input, seed input and volume of pesticides used. The factors that were positive and significantly influencing output of maize production include: farm size $(P<0.01)$, family labour $(P<0.05)$, hired labour $(P<0.05)$, fertilizer input $(P<0.01)$, seed input $(P<0.05)$, and volume of pesticides used $(P<0.05)$. The elasticity of production for farm size was 0.7634 . This implies that a unit increase in farm size will lead to 0.7643 increases in output of marginal maize production.

The elasticity of production for fertilizer input was 0.2387 . This implies that a unit increase in the use of fertilizer by marginal maize farmers will lead to 0.2387 increases in output of maize production. The return to scale (RTS) which is the summation of the elasticity of production for all resources used was estimated to be 4.1126. This implies that it is an increasing return to scale. The coefficient of multiple determinations $\left(R^{2}\right)$ was 0.7854 . This implies the explanatory or exogenous or independent variables included in the model explained $78.54 \%$ of the explained or predictant or response or dependent variable. The $\mathrm{F}$ value of 366.45 was significant at $P<0.01$ ). This explained that all exogenous variables 
included in the model explained the variations in the response variable. This result agrees or is in line with findings of Alabi and Ibraheem (2018), Alabi and Ajooku (2012).

Table 4 - Factors Influencing or Affecting Output of Marginal Maize Production

\begin{tabular}{|l|l|l|l|}
\hline \multicolumn{1}{|c|}{ Variable } & \multicolumn{1}{|c|}{ Regression Coefficient } & \multicolumn{1}{c|}{ Standard Error } & \multicolumn{1}{c|}{-Statistics } \\
\hline Farm Size $\left(\mathrm{X}_{1}\right)$ & 0.7634 & 0.2561 & $2.98^{\star * *}$ \\
Family Labour $\left(\mathrm{X}_{2}\right)$ & 0.6437 & 0.2534 & $2.54^{\star *}$ \\
Hired Labour $\left(\mathrm{X}_{3}\right)$ & 0.6891 & 0.2580 & $2.67^{\star *}$ \\
Fertilizer $\left(\mathrm{X}_{4}\right)$ & 0.0793 & $3.01^{\star * *}$ \\
Seed Input $\left(\mathrm{X}_{5}\right)$ & 0.2387 & 0.3034 & $2.75^{\star *}$ \\
Pesticides $\left(\mathrm{X}_{6}\right)$ & 0.8345 & 0.4491 & $2.10^{*}$ \\
RTS & 0.9432 & & \\
Constant & 4.1126 & & \\
$\mathrm{R}^{2}$ & 1.4532 & & \\
Adjusted $\mathrm{R}^{2}$ & 0.7854 & & \\
F-Value & 0.7532 & & \\
\hline
\end{tabular}

Source: Field Survey (2019), Computed using STATA Version 14.

${ }^{* *}$ Significant at $P<0.01,{ }^{* *}$-Significant at $P<0.05$, ${ }^{* *}$-Significant at $P<0.10$.

Double-Hurdle Model Results of Market Participations by Marginal Maize Farmers. The results of Double -Hurdle model for factors influencing market participations by marginal maize farmers were presented in Table 5. Exogenous or regressor variables that were examined in the model include: age, marital status, educational status, distant to nearby market, access to extension agents, and access to credit facilities. The Wald Chi-square value was 176.54 for decisions made by marginal maize farmers to participate in market, and this was statistically significant at $(P<0.01)$. This indicates that the variables included in the model jointly provides explanations for the probability for marginal maize farmers to participate in the market.

Marginal maize farmers decisions to participate in the market were statistically and significantly determined by age $(P<0.01)$, prices output of maize $(P<0.05)$, educational status $(P<0.10)$, distant to nearby market $(P<0.05)$, access to extension agents $(P<$ $0.01)$, and access to credit facilities $(P<0.05)$. Access to credit facilities was positive, statistically and significantly influence the probability or likelihood of marginal maize farmers in market participations at $(P<0.01)$. This means that as marginal maize farmers shift from non- access to access of credit facilities by one unit has increase the probability or likelihoods of marginal maize farmers decisions to participate in market by $11.61 \%$. This results agrees or in line with findings of Randela et al (2008), Alene et al (2008). Age and educational status positively and significantly influence the likelihood or probability of marginal maize farmers decisions in market participations at $(P<0.05)$ and $(P<0.01)$ respectively. As farmers get educated and advanced in age, there are high probability and likelihoods that the farmers decisions to participate in accessing the market. A unit increase in level of education will lead to $16.21 \%$ increases in market participation by marginal maize farmers. This result agrees or is in line with Olawande and Mathenge (2010). Second stage of Double-Hurdle model considered factors influencing intensity of market participation. Six (6) exogenous variables included in the model were found to be positively and negatively but significantly influences the intensity of market participation by marginal maize farmers. The explanatory variables were; age $(P<0.01)$, marital status $(P<0.05)$, educational status $(P<0.01)$, distant to nearby market $(P<0.01)$, access to extension agents $(P<0.05)$, and access to credit facilities $(P<0.01)$. Distant to the nearest market negatively and statistically significantly influences intensity of market participation at $1 \%$ probability level. When the markets are located at $1 \mathrm{~km}$ away from the maize farmers household, the level of markets participation decreases by $17.81 \%$. This result agrees or is in line with findings of Zamasiya et al (2014).

Principal Component Analysis (PCA) of Constraints or Problems Facing Marginal Maize Farmers. Table 6 shows the results of the constraints or problems facing marginal maize farmers. Principal Component Analysis can be defined as a statistical applications or 
techniques that transforms data with many and interrelated variables into few and small numbers which were uncorrelated.

Table 5 - Double-Hurdle Estimates of Marginal Maize Farmers Market Participation

\begin{tabular}{|c|c|c|c|c|c|c|}
\hline Variable & \multicolumn{2}{|c|}{ First Hurdle } & & \multicolumn{3}{|c|}{ Second Hurdle } \\
\hline & Coefficient & Std. Error & $\begin{array}{l}\text { Margina } \\
\text { Effects }\end{array}$ & Coefficient & Std. Error & $\begin{array}{l}\text { Marginal } \\
\text { Effects }\end{array}$ \\
\hline $\operatorname{Age}\left(X_{1}\right)$ & $0.1451^{* * *}$ & 0.1321 & 0.1691 & $0.1611^{* * *}$ & 0.4689 & 0.1611 \\
\hline Prices Output of Maize $\left(X_{2}\right)$ & $0.1332^{* *}$ & 0.1421 & 0.1434 & $0.1721^{* *}$ & 0.4319 & 0.1721 \\
\hline Education Status $\left(X_{3}\right)$ & $0.1221^{*}$ & 0.1131 & 0.1621 & $0.1861^{* \star *}$ & 0.7462 & 0.1861 \\
\hline Distant to Nearby Market $\left(X_{5}\right)$ & $0.1931^{* *}$ & 0.1343 & 0.1731 & $-0.1781^{\star * *}$ & 0.6994 & 0.1781 \\
\hline Access to Extension Agents $\left(X_{6}\right)$ & $0.1621^{\text {*** }}$ & 0.1421 & 0.1521 & $0.1631^{* *}$ & 0.4241 & 0.1631 \\
\hline Access to Credit Facilities $\left(X_{7}\right)$ & $0.1439^{* *}$ & 0.1161 & 0.1861 & $0.1521^{\text {*** }}$ & 0.5491 & 0.1521 \\
\hline Constant & 0.1341 & 0.2141 & & 0.1441 & 0.1679 & \\
\hline No of Observation & 100 & & & & & \\
\hline Wald Chi Square & 176.54 & & & 181.31 & & \\
\hline Log-Likelihood & -104.96 & & & -109.32 & & \\
\hline Prob $>\mathrm{Chi}^{2}$ & 0.0000 & & & 0.0000 & & \\
\hline
\end{tabular}

Source: Field Survey (2019), Computed using STATA Version 14.

${ }^{* * *}$ Significant at $P<0.01,{ }^{* *}$-Significant at $P<0.05$, ${ }^{* *}$-Significant at $P<0.10$.

Table 6 - Results of the Principal Component Analysis of Constraints or Problems Facing Marginal Maize Farmers

\begin{tabular}{|l|l|l|l|l|}
\hline Constraints & Eigen-Value & Difference & Proportion & Cumulative \\
\hline Bad Road Infrastructure & 3.1671 & 0.1163 & 0.1001 & 0.1001 \\
Lack of Access to Credit Facilities & 2.1338 & 0.8251 & 0.1231 & 0.2232 \\
Inadequate Extension Officers & 2.1160 & 0.3221 & 0.1721 & 0.3953 \\
Poor Storage Facilities & 1.1831 & 0.2993 & 0.1841 & 0.5794 \\
Lack of Production Inputs & 1.1991 & 0.3114 & 0.1911 & 0.7705 \\
Lack of New Improved Technologies & 1.2109 & 0.3106 & 0.1941 & 0.9646 \\
\hline Bartlett Test of Sphericity & \multicolumn{5}{l}{} \\
KMO 0.723 & \multicolumn{5}{l}{} \\
Chi-Square 3071.119*** & & \\
Rho 1.00000
\end{tabular}

Source: Field Survey (2019), Computed using STATA Version 14.

The number of principal components retained using the Kaiser Meyer criterion were six (6) based on the Eigen value greater than 1. The retained components observed explained $96.46 \%$ of the variations of the components included in the model. The Kaiser-Meyer-Olkin which measures sampling adequacy (KMO) gave an estimated value of 0.723 and the Bartlett test of sphericity of 3071.119 was observed to be significant at $1 \%$ (one percent) level of probability. This demonstrated the feasibility of using the data set for factor analysis. Bad road infrastructures had an Eigen value of 3.1671 and it was ranked $1^{\text {st }}$ in the order of importance based on perceptions of the marginal maize farmers. Lack of access to credit facilities and inadequate extension officers with Eigen values of 2.1338 and 2.1160 were ranked $2^{\text {nd }}$ and $3^{\text {rd }}$ respectively in the order of occurrence based on the perceptions of marginal maize farmers as the major problems or constraints facing market participation by the marginal maize farmers. Also, poor storage facilities and lack of production inputs with Eigen values of 1.1831 and 1.1991 were ranked $4^{\text {th }}$ and $5^{\text {th }}$ in order of their occurrence and importance respectively based on the perceptions of marginal maize farmers as other problems or challenges faced by the enterprise.

\section{CONCLUSION}

Marginal maize production is profitable. The gross margin ratio of 0.82 implies that for every one naira invested in maize production 82 kobo covered profits, taxes, interest, expenses and depreciation. The mean farm size was 1.19 hectares of land. Marginal 
productivity analysis revealed that fertilizer input, seed input, and land input were the resources under-utilized. Labour input was over-utilized. Farm size, family labour, hired labour, fertilizer input, seed input and volume of pesticides used were statistical and significant factors influencing output of maize produced by marginal farmers. Age, prices output of maize, education status, distant to nearby market, access to extension agents, and access to credit facilities were statistically and significant factors influencing the likelihoods or probability of market participations, and also the intensity of market participations by marginal maize farmers. Bad road infrastructures, lack of access to credit facilities, inadequate extension officers, poor storage facilities, lack of production inputs, and lack of new improved technologies were retained variables as major constrains or problems influencing marginal maize farmers from market participation. The retained components explained $96.46 \%$ of all constraint variables included in the model.

\section{RECOMMENDATIONS}

The following under-listed points were recommended based on the findings of this study:

(a) Government should provide production inputs, such as improved seeds, fertilizers, pesticides, for maize farmers to increase productivity.

(b) Credit facilities should be made available and accessible for farmers at low interest rate with little or no administrative procedures to increase output.

(c) Extension agents should be provided to disseminate research findings and new, improved technologies to marginal maize farmers to increase productivity.

(d) Access and motorable road infrastructures with good transport vehicles should be provided for easy evacuation of maize produce to nearby market.

\section{REFERENCES}

1. Alene, A.D, Manyong, V.M, Omanya, G, Mignouna, H.D, Bokanga, M and Odhiambo, G (2008). Smallholder Market Participation under Transaction Costs: Maize Supply and Fertilizer Demand in Kenya. Food Policy Vol 33: 318 - 328.

2. Alabi, O.O. and Ibraheem, A (2018). Economics of Maize (Zea mays) Production in Igabi Local Government of Kaduna State, Nigeria. Journal of Agricultural Faculty of Gaziosmanpasa University (JAFAG).Volume 35 (3): 248-257.

3. Alabi, O.O; Amadi, M.U; and ljir, T.S (2014).Determinants of Gross Income Among Smallscale Sorghum Producers in Gwagwalada Area Council of the Federal Capital Territory (FCT) Abuja, Nigeria, Agricultural Economics and Extension Research Studies (AGEERS), 3 (1):16-26.

4. Alabi O.O. and Ajooku, H.A (2012).Socio-Economic Factors Influencing Cassava Production in Kuje and Abaji Area Councils of Federal Capital Territory, Abuja, Nigeria, Journal of Agriculture, Forestry and Social Sciences (JOAFSS), 10(2):73-84.

5. Barrett, C.B (2008). Displaced Distortions: Financial Market Failures and Seemingly Inefficient Resources Allocation in Low -Income Rural Communities. In: Bulte, E., Ruben, R (Eds). Development Economics between Markets and Institutions: Incentives for Growth, Food Security and Sustainable Use of the Environment, Wageningen Academic Publishers.

6. Ben-Chendo, G.N, N. Lawal, M.N. Osuji, I.I. Osugiri, and B.O. Ibeagwa, (2015). Cost and Returns of Paddy Rice Production in Kaduna State of Nigeria. International Journal of Agricultural Marketing 2(5):084-089.

7. Gyau, A, Mbugua, M, and Oduol, J (2006). Determinants of Participation and Intensity of Participation in Collective Action: Evidence from Smallholder Avocado Farmers in Kenya. Journal of Chain and Network Science, Volume 16: $147-156$.

8. Jensen, R.T (2010). Information, Efficiency, and Welfare in Agricultural Markets. Agricultural Economics 41 (1); $203-216$. 
9. Lowder, S.K, Skoet, J, and Raney, T (2016). The Number, Size, and Distributions of Farms, Smallholder Farms, and Family Farms Worldwide. World Development 87: 16 29.

10. Mulat, D, Fantu, G and Tadele, F (2006). Agricultural Development and Food Security in sub-Saharan Africa (SSA), Bulding the Case for More Public Support, the Ethiopia Case Study, FAO, Rome, 2006.

11. Olawande, J and Mathenge, M (2010). Market Participation among Poor Rural Households in Kenya. Paper Prepared for Presentation at International Association of Agricultural Economics (IAAE), Brazil, August, 18 - 24.

12. Oluwatayo, I.B; Sekumade, A.B; and Adesoji, S.A (2008). Resource-Use Efficiency of Maize Farmers in Rural Nigeria: Evidence from Ekiti State. World Journal of Agriculture Sciences 4(1).

13. Olukosi, J.O. and Erhabor, P.O. (2005). Introduction to Farm Management Economics: Principles and Applications. Agitab Publishers Limited, Zaria, Kaduna, Nigeria. pp.77-83.

14. Ojo, S.O (2000). Factors Productivity in Maize Production in Ondo State, Nigeria. Applied Tropical Agriculture 15 (1): $57-63$.

15. Randela, R, Alemu, Z.G and Groenewald, J.A (2008). Factors Enhancing Market Participation by Smallscale Cotton Farmers, Agrekon Vol 47 No 4.

16. Reardon, T, Chen, K, Minten, B and Adriano, L (2012). The Quiet Revolution in Staple Food Value Chains. Enter the Dragon. The Elephant, and the Tiger. Mandaluyong City, Phillipines: Asian Development Bank (ADB); Int Food Policy Res Inst (IFPRI).

17. Uchenzuba, I.D, Moshabele, E and Dogopo, D (2009). Logistical Estimation of the Probability of Mainstream Market Participation among Smallscale Livestock Farmers: A Case Study of the Northern Cape Province Agrekon 48 (2): 171 - 183.

18. Udoh, A.J and Nyienakuma, M.G (2008). Examining Socio-Economic Characteristics and Adoption Trends of Artisanal Fishers of Akwa lbom State in West Africa. Journal of Agriculture Social Science 4:141-146.

19. Zamasiya, B, Mango, N Nyikahadoi, K and Siziba, S (2014). Determinants of Soybean Market Participation by Smallholder Farmers in Zimbabwe. Journal of Development and Agricultural Economics 6 (2): 49 - 58 . 